\title{
REMEDIATION OF SOIL POLLUTED WITH THIAMETHOXAM USING GREEN NANO - PHYTOTECHNOLOGY
}

M.R.Ramadan; Muhanna, A. H. and Romeh, A. A.

Plant Production Department, Faculty of Technology and Development, Zagazig University, Zagazig, Egypt

\section{ABSTRACT}

Nano zero-valent iron prepared from Marjoram (Mar-nZVI) and nano zero-valent iron prepared from Moringa (Mor-nZVI), with and without Helianthus annuus $L$. for the removal of thiamethoxam pesticide from soil has been investigated. Structure and morphology of Mar-nZVI and Mor-nZVI, were characterized by UV spectroscopy and High-resolution transmission electron microscopy (HRTEM).

The results showed that the Mar-nZVI played the most important role in the removal of thiamethoxam in the soil, compared with natural degradation in soil without $n Z V I$. The percent removal of thiamethoxam in the soil by Mar-nZVI and Mor-nZVI reached 75.13 and $66.83 \%$ respectively, compared with $61.06 \%$ in soil without nZVI through 12days. Thiamethoxam was removed more quickly in the presence of $H$. annuus plus nZVI than that by $H$. annuus alone. Thiamethoxam uptake into the $H$. annuus roots at high level and reached the maximum $17.35 \mu \mathrm{g} / \mathrm{g}$ after 6 days of exposure. While, in $H$. annuus roots treated with Mar-FeNps and Mor-FeNps reached 9.51 and $11.60 \mu \mathrm{g} / \mathrm{g}$, respectively. The accumulation of thiamethoxam in $H$. annuus leaves were lower efficient under the treatments of $H$. annuus L. plus $n Z V I$ than that by $H$. annuus alone. This is attributed to the role of nZVI alone in degradation of thiamethoxam in soil.

Therefore, the concentration of thiamethoxam was more decreased in the roots and in the leaves of $H$. annuus

Conclusively, from these results it be concluded that helianthus annuus L. plus nZVI plays a major role for the remediation of thiamethoxam-contaminated soil.

Keywords: Thiamethoxam, green nanotechnology, phytoremediation, soil. 


\section{INTRODUCTION}

Pesticides are the chemical intended to control the pests and weeds. They are widely used in agricultural fields to protect the crops from pest damages. Among the pesticides, find huge applications in the agricultural fields. However, more than $90 \%$ of the sprayed pesticides reach the destinations other than their targets because they are sprayed over the entire agricultural field. These chemicals reach the water bodies via agricultural run-offs, direct entry from the spray, industrial effluents, and dust (Khatri and Tyagi, 2015), causing decreases the quality of water (Khatri et al., 2016). In addition, Residues of pesticides have significant environmental impacts on aquatic ecosystems and mammals (Joo and Cheng, 2006 and Maddah and Hasanzadeh, 2017). Thiamethoxam 1, (3-[(2-chloro-5thiazolyl) methyl] tetrahydro-5- methyl-N-nitro-4H-1,3,5-oxadiazin-4imine), thiamethoxam, one of the most commonly used pesticides from the neonicotinoid group. Thiamethoxam is the first representative of secondgeneration neonicotinoids and belongs to the thia-nicotinyl sub-class. It is marketed under the trademarks Actara ${ }^{\circledR}$ for foliar and/or soil treatment (of crops include fruiting vegetables, cucurbits, potatoes, pome, stone fruit, tobacco, pecans, strawberries, and cotton) and Cruiser® for seed treatments on a wide variety of crops including corn, cotton, sorghum, barley, wheat, potatoes, sunflowers, and legumes (Robinson, 2001; Simon-Delso et al., 2015). The compound has a broad-spectrum insecticidal activity and offers excellent control of a wide variety of commercially important pests in many crops (Maienfisch et al., 2001). Thiamethoxam has a relatively long half-life in soil and high water solubility (average $\mathrm{DT}_{50}=229$ days, $4,100 \mathrm{mg} / \mathrm{L}$ ) which means it is persistent in the environment with high potential to be transported into surface water via run-off or groundwater discharge (Main et al., 2014). A recent survey of water monitoring literature focusing on surface water contamination by neonicotinoids, found thiamethoxam levels to range from 0.001 to $225 \mathrm{ppb}$ (Morrissey et al., 2015). However, its characteristic properties, such as low soil sorption and high leaching capability, make it a potential contamination source of underground and surface waters (Muccio et al., 2006). The detailed chemistry of thiamethoxam, its metabolism, bioavailability, human toxicology, ecotoxicology, approved uses, analytical procedures and potential risks are well documented in the literature (GOA, 2001and HCPMRA, 2001). Few studies related to degradation of thiamethoxam include, hydrolysis and direct photolysis (De urzedo et al., 2007 and Zheng et al., 2006).

Nanotechnology is the development and utilization of structures with a size range from $1 \mathrm{~nm}$ to about $100 \mathrm{~nm}$ where new physical, chemical and 
biological properties occur such as extremely small size, high surface area to volume ratio, surface modifiability and excellent magnetic properties (Riu et al., 2006). In recent years, zero-valent iron (ZVI) has been widely applied for treatment of contamination because of its easy accessibility, effective degradation of pollutants, generation of very little waste and secondary pollutants (Joo and Cheng, 2006 and Thompson et al., 2010).

Many researchers have reported the green synthesis of iron nanoparticles using various plant extracts. Biosynthesis of iron nanoparticles (Fe NPs) has been mainly performed using extract of green tea, which is a cheap and local resource. (Hoag et al.,2009). $\mathrm{Fe} 0 / \mathrm{Fe} 3 \mathrm{O} 4$ nanoparticles were successfully synthesised using pomegranate (Punica granatum) leaf extract by (Rao et al., 2013). Makarov et al., (2014) reported the synthesis of iron oxide nanoparticles using aqueous extract of Hordeum vulgare and Rumex acetosa.

Therefore, the objective of this study was to investigate the effects of green nanotechnology (iron nanoparticles from medicinal plant extracts, $\mathrm{Fe}^{0}$ ) and Helianthus annuus L. for remediation of thiamethoxam from soil.

\section{MATERIALS AND METHODS}

\section{Pesticide and Plant Material}

Thiamethoxam 25\% W G was obtained from the Central Agriculture Pesticide Laboratory, Agriculture Research Center, 7 Nadi EL Said St., Dokki, Giza, Egypt. Sunflower, (Helianthus annuus L.) seeds were germinated in vermiculite growing medium and kept moist during the initial growth period (1 week), which may vary according to plant type. After the germination period, only healthy seedlings with uniform size were selected. Plants were then gently removed from growing medium, and the roots were rinsed off from any adhering material before transferring to the soil.

\section{Synthesis of nano zero-valent iron (nZVI)}

The nano zero-valent iron prepared from Marjoram (Mar-nZVI) and Moringa (Mor-nZVI) were prepared according to the method described by (Abbassi et al., 2013).

For the synthesis of Mar-nZVI and Mor-nZVI, $20 \mathrm{~g}$. of each dry Marjoram (Origanum majorana L) and Moringa (Moringa oleifera Lam) leaves powder were heated up to $80^{\circ} \mathrm{C}$ in $1 \mathrm{~L}$ deionized water and filtered using a vacuum filter. A solution of $0.1 \mathrm{M} \mathrm{FeCl}_{3}$ was prepared by dissolving solid $\mathrm{FeCl}_{3}$ in $1 \mathrm{~L}$ of deionized water. This solution was mixed for $1 \mathrm{~h}$ using a stirrer. After mixing, the mixture was centrifuged at $5000 \mathrm{rpm}$ for $30 \mathrm{~min}$ 
and washed three times with ethylene to remove the residual ferric chloride. The wet paste was then dried in an oven at $60{ }^{\circ} \mathrm{C}$ overnight, and the final product was grinded before use in the experiment.

\section{Characterization and measurements of zero-valent iron (nZVI)}

The formation and stability of iron nanoparticles (FeNps) was done by using UV-vis spectrophotometer (Version 530). The absorption spectrum of reaction solutions were recorded at wavelengths ranging from 200 to 500 nm (Narayan and Park 2014).

The morphology, size and shape of $\mathrm{F}_{-} \mathrm{Fe}^{0}$ were performed by Highresolution transmission electron microscopy (HRTEM), JOEL model JEM2100 using an accelerating voltage of $200 \mathrm{kV}$. Sample preparation for TEM analysis involves depositing a drop of aqueous $\mathrm{F}-\mathrm{Fe}^{0}$ suspension on a carbon- coated copper grid and allowed to dry at room temperature; the transmission electron micrographs is used for recording the particle size and morphology. HRTEM Samples were determined at Al-Azhar University.

\section{Experimental design}

The potential of Mar-nZVI and Mor-nZVI with and without $H$. annuus for removing thiamethoxam from aqueous solution $(100 \mathrm{ml})$ at an initial concentration of $20 \mathrm{mg} / \mathrm{L}$ were evaluated.

The experiment used a pot assay; the pot-culture experiment was arranged in a randomized design that contained six treatments and each treatment consisted of three replicates: (1) Thiamethoxam -contaminated soil with no plants, (2) Thiamethoxam -contaminated soil with $H$. annuus seedling, (3-6) Thiamethoxam -contaminated soil amended with Mar-nZVI and Mor-nZVI separately, with and without a $H$. annuus. A water solution of thiamethoxam was carefully added to the pots to avoid direct contact with the plant shoots. Two milliliters of each FeNps (2.0\%) was diluted to $100 \mathrm{ml}$ of water and amended to the soil (treatments, 3-6) until flooding ( $2 \mathrm{~cm}$ over the soil) to maintain an anaerobic condition, while treatments 1 and 2 were amended with water alone until flooding.

\section{Sampling and analysis}

After 1, 3, 6 and 12 days post treatment, Plant roots from the soil were rinsed in running tap water then blotted, $5 \mathrm{~g}$ of leaves, $5 \mathrm{~g}$ of roots and $10 \mathrm{~g}$ of soil were analyzed for the determination of thiamethoxam residues by high-performance liquid chromatography (HPLC). Thiamethoxam extracted from soil using the quick, easy, cheap, rugged and safe, QuEChERS. Soil samples were homogenized sieved $(2 \mathrm{~mm}$ mesh) and air-dried at room temperature. A $10 \mathrm{~g}$ portion of soil was weighed into a $50 \mathrm{~mL}$ 
polypropylene tube, then $5 \mathrm{~mL}$ of HPLC water was added and the mixture was energetically shaken for $1 \mathrm{~min}$ with a vortex device. After that, $10 \mathrm{~mL}$ of acetonitrile was added (acidified with acetic acid 1\%, v/v for quinmerac analysis) and the mixture was shaken for $1 \mathrm{~min}$ by hand and for $1 \mathrm{~min}$ with a vortex device.

Four grams of anhydrous magnesium sulfate, and $1 \mathrm{~g}$ sodium chloride were aded, and the mixture was immediately hand-shaken for $30 \mathrm{~s}$, and centrifuged for $5 \mathrm{~min}$ at $4000 \mathrm{rpm}$ in a Sigma 2-5 centrifuge (Sigma, Steinheim, Germany). Then, a clean-up dispersive solid phase extraction step was carried out by adding the supernatant $(7.5 \mathrm{~mL}$, i.e. $1.33 \mathrm{~g}$ of soil per $\mathrm{mL}$ ), to a $15 \mathrm{~mL}$ polypropylene tube that contained $1.125 \mathrm{~g}$ of $\mathrm{MgSO} 4$ (150 mg MgSO4 per mL of extract) and $0.225 \mathrm{~g}$ of $\mathrm{C}_{18}(30 \mathrm{mg} \mathrm{C} 18$ per $\mathrm{mL}$ of extract), hand-shaken for $30 \mathrm{~s}$ and centrifuged for $5 \mathrm{~min}$ at $4000 \mathrm{rpm}$ (Asensio-Ramos et al., 2010 and Padilla-Sanchez et al., 2010). For the determination of two pesticides, $1.0 \mathrm{ml}$ of the final extract was analysed by HPLC. Fresh root and leaf samples were chopped, mixed well, and then homogenized with dry ice using a high-speed blender. Extraction and cleanup were conducted using QuEChERS method introduced by (Lehotay et al., 2010) and modified as follows: Finely samples $(5 \mathrm{~g})$ were weighed into $50 \mathrm{~mL}$ Teflon centrifuge tubes; $8 \mathrm{~mL}$ of acetonitrile and $2 \mathrm{~mL}$ of methanol were added together and the samples were shaken vigorously for 1 min by shaker to ensure the solvent interacted well with the entire samples. The sample tubes were then stored in a refrigerator at $-20^{\circ} \mathrm{C}$ for $20 \mathrm{~min}$. After that, $4 \mathrm{~g} \mathrm{MgSO}_{4}$ and $1 \mathrm{~g} \mathrm{NaCl}$ were added and the samples were vortexed immediately for $1 \mathrm{~min}$. The extracts were then centrifuged for 5 $\mathrm{min}$ at $5000 \mathrm{rpm}$. From the upper layer of the prepared sample, $2 \mathrm{~mL}$ of the samples were transferred into a $10 \mathrm{~mL}$ tube containing $25 \mathrm{mg}$ PSA sorbent, $125 \mathrm{mg} \mathrm{MgSO}{ }_{4}$ and the samples were again vortexed for $1 \mathrm{~min}$ and then centrifuged for $5 \mathrm{~min}$ at $5000 \mathrm{rpm}$. The obtained residue was finally filtered using a $0.22 \mu \mathrm{m}$ Nylon syringe filter for HPLC analysis.

The operating parameters were as follows: a $\mathrm{C}_{18}$ reversed-phase column was used $(250 \times 4.0 \mathrm{~mm}$ i.e. $)$, mobile phase consisted of $100 \%$ acetonitrile with isocratic mode at a flow rate of $1.0 \mathrm{~mL} / \mathrm{min}$, and $\mathrm{UV}$ detection at $280 \mathrm{~nm}$.

The injection volume was $10 \mu \mathrm{L}$ for quantitative analysis. The retention time of Thiamethoxam was $2.83 \mathrm{~min}$.

The removal efficiency of thiamethoxam was calculated as follows:

Removal $(\%)=\left(\mathrm{C}_{0}-\mathrm{C}_{\mathrm{e}}\right) / \mathrm{C}_{0} \times 100$

Where: $\mathrm{C}_{0}$ and $\mathrm{C}_{\mathrm{e}}$ are the concentration of Thiamethoxam at initial post treatment of each period $\mu \mathrm{g} / \mathrm{ml}$, or $\mu \mathrm{g} / \mathrm{g}$. 


\section{RESULTS AND DISCUSSION}

\section{Characterization}

The surface plasmon resonance (SPR) peaks were found to be $r \leqslant r$ and $r \leqslant$ ), respectively, for FeNps from Origanum majorana L and Moringa oleifera Lam (Figure $1 \mathrm{a} \& \mathrm{~b}$ ), causing the synthesis of FeNps in the size from 2 to 100 nm (Bar et al., 2009; Philip et al., 2011 and Mittal et al., 2013).

The analysis of electron microscopy shows that the formed nanoparticles of nano zero-valent iron prepared from Marjoram (Mar-nZVI), and B, zerovalent iron prepared from Moringa (Mor-nZVI) were circular shapes and sizes. The Mar-nZVI and Mor-nZVI were well separated and there was no agglomeration. The shapes of nanoparticles were circular, with sizes lower than 100nm (Figure 2. A\& b).
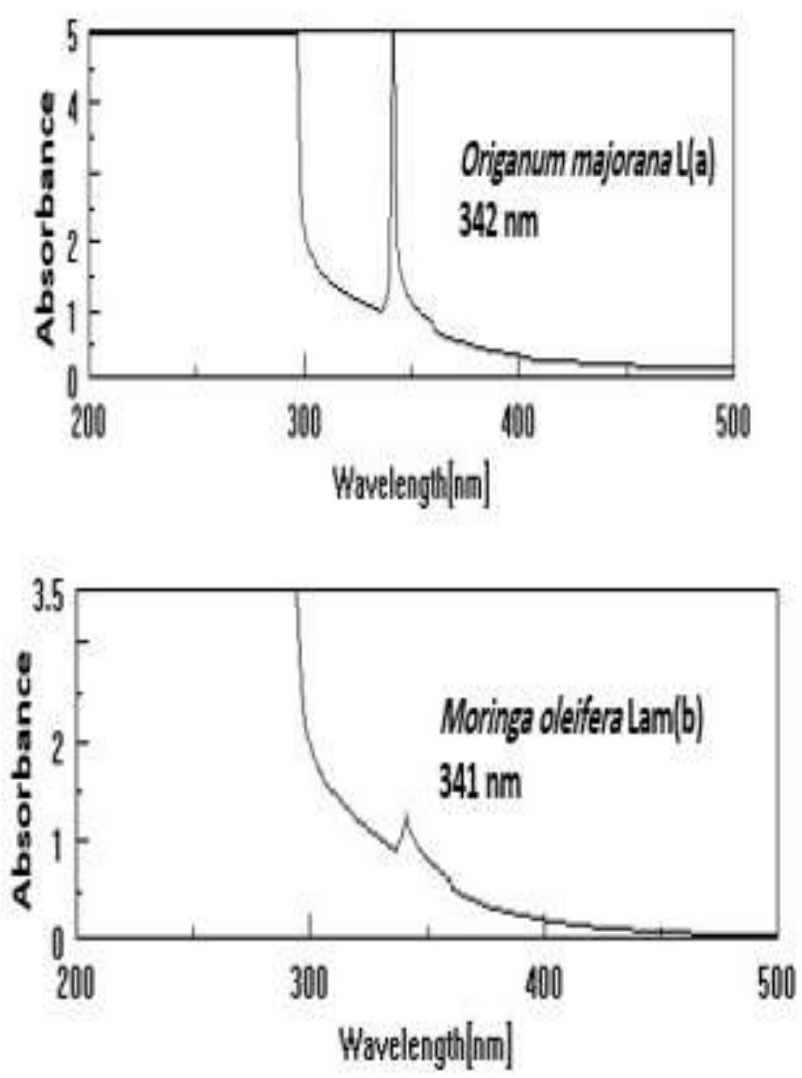

Figure(1). UV-visible spectroscopy of iron nanoparticles (FeNps) synthesized with two medicinal plant leaf extracts in $0.1 \mathrm{M} \mathrm{FeCl}_{3}$ solution. (a) Marjoram FeNps. (b) Moringa - FeNps. 


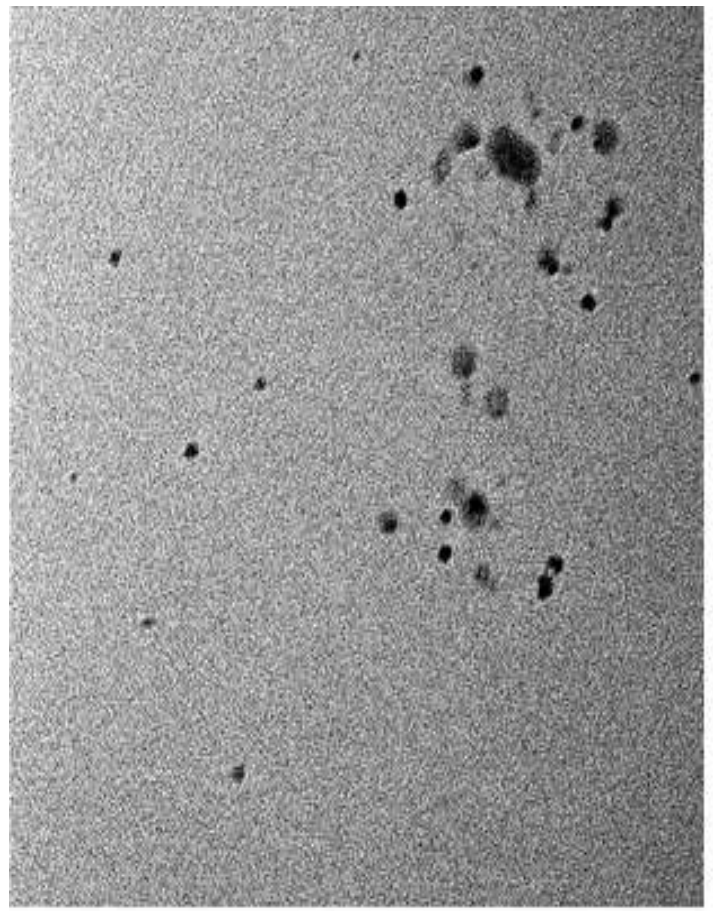

$\overline{100 \mathrm{~nm}}$

$100 \mathrm{nh}$
A, Mar-nZVI

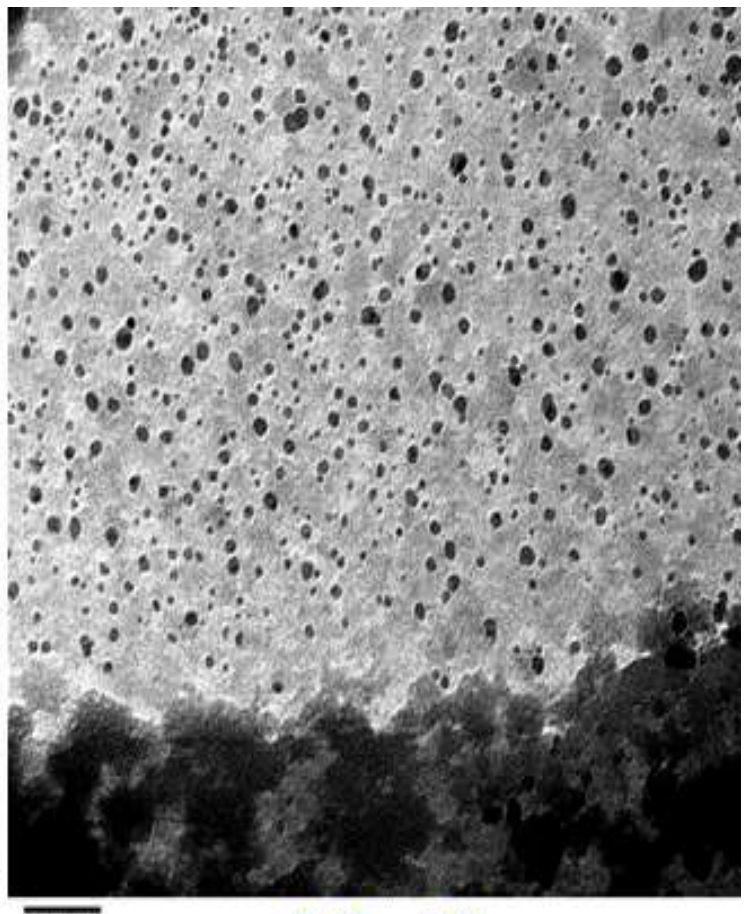

B, Mor-nZVI

Figure 2. High-resolution transmission electron microscopy (HRTEM).A, nano zero-valent iron prepared from Marjoram (Mar-nZVI), and B, zerovalent iron prepared from Moringa(Mor-nZVI).

\section{Remediation of soil polluted by thiamethoxam by $n Z V I$}

The preparation of nano zero-valent iron prepared from Marjoram (Mar-nZVI) and nano zero-valent iron prepared from Moringa (Mor-nZVI with and without $H$. annuus for the removal of thiamethoxam pesticide from flooded soil has been investigated in Figures (3 and 4).

The percent removal of thiamethoxam in the soil by Mar-nZVI and Mor-nZVI reached 75.13 and $66.83 \%$ respectively, compared with $61.06 \%$ in soil without nZVI through 12days (Figure 4). The results showed that the Mar-nZVI played the most important role in the removal of thiamethoxam in the soil, compared with natural degradation in soil without nZVI. Studies have shown that many pesticides can be destroyed using ZVI. It also has been successfully used in dechlorination of highly recalcitrant pesticides and herbicides (Doong and Lai,2006 and Sayles et al., 1997). When halogenated organic pollutants are treated with ZVI, oxidation of ZVI and $\mathrm{Fe}(\mathrm{II})$ provides electrons for dechlorination (Satapanajaru et al., 2008). Young-Soo 
and Li (2003) studied the reduction of eleven nitroaromatic pesticides with zero-valent iron powder.

The removal of other pollutants such as chlorinated organic compounds, pesticides, phenols, amines, and organic acids through such nanoparticles has been studied (Wang et al., 2013). Nanoscale iron particles are very effective for the transformation and detoxification of a wide variety of common environmental contaminants, such as chlorinated organic solvents, organochlorine pesticides, and polychloro biphenyls (Elliott and Zhang, 2001; Glazier et al., 2003; Ivanov et al., 2004; Quinn et al., 2005 and Mauter and Elimelech, 2008). The iron-based soil treatment has shown promising results over relatively long treatment periods (e.g., up to six years) in a variety of contaminated soils (Mench et al., 2006).

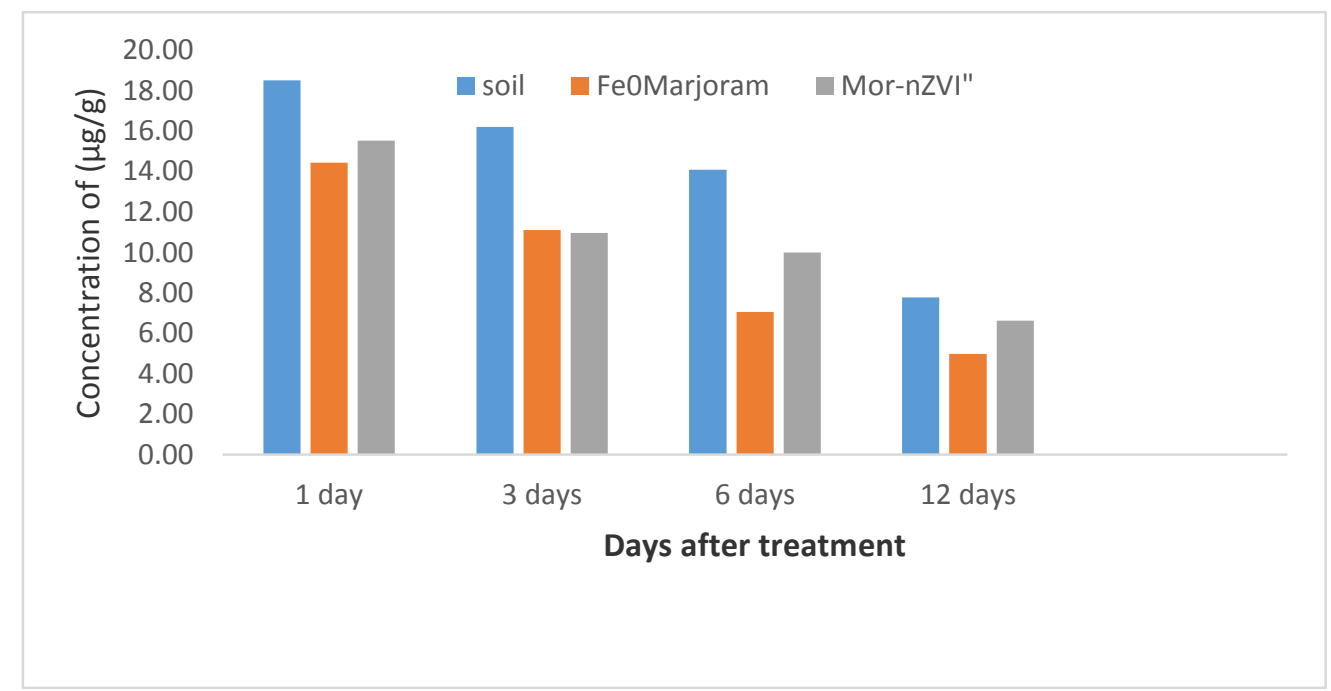

Figure (3) Degradation of thiamethoxam in soil by zero-valent iron nanoparticles. 


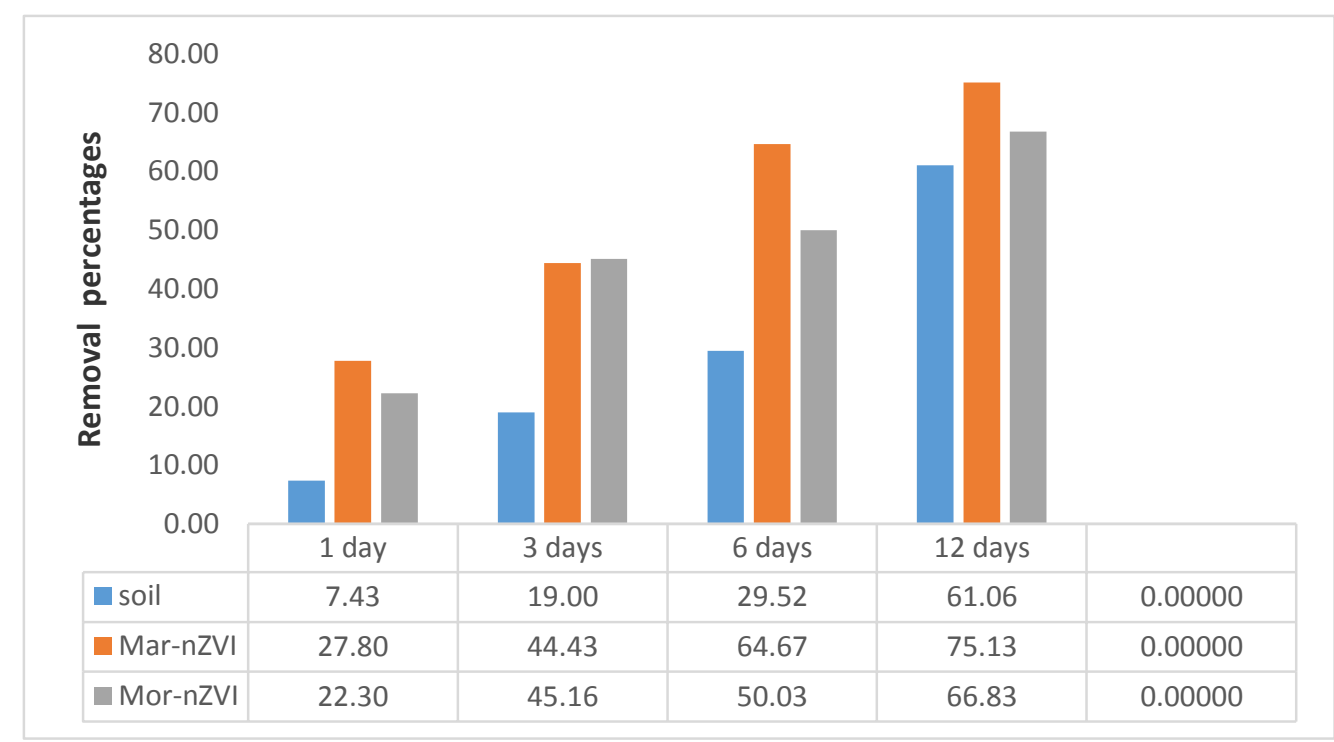

Figure (4) Percent removal of thiamethoxam in soil by zero-valent iron nanoparticles.

\section{Nano-Phytotechnological removal of thiamethoxam polluted soil}

The degradation of thiamethoxam by FeNps amended with $H$. annuus in flooded soil is shown in Fig. 5. The percent removal of thiamethoxam by Mar-nZVI amended with $H$. annuus, Mor-nZVI amended with $H$. annuus and $H$. annuus alone in flooding soil within 12 days was 89.46, 80.98, and $77.32 \%$, respectively (Fig. 5). The degradation percentage of thiamethoxam in the controls without FeNps and without $H$. annuus within 12 days was $61.06 \%$ (Fig. 4). Thiamethoxam was removed more quickly in the presence of $H$. annuus plus nZVI than that by $H$. annuus alone (Table 1). Soil moisture played an important role to increase ionization and activation of nZVI (Kim et al., 2010). This may be because soil saturation with water decreases the oxygen levels and thus prevent the oxidation of nZVI (ElTemsah and Joner, 2013).

Pesticides, which are persistent in aerobic environments, are more readily degraded under reducing conditions (Comfort et al., 2001). Data in Table 1 and Fig. 5 showed that thiamethoxam uptake into the $H$. annuus roots at high level and reached the maximum $17.35 \mu \mathrm{g} / \mathrm{g}$ after 6 days of exposure, While, in $H$. annuus roots treated with Mar- FeNps and MorFeNps reached 9.51 and $11.60 \mu \mathrm{g} / \mathrm{g}$, respectively, may be due to increasing degradation processes in soil by FeNps. The accumulation of thiamethoxam in $H$. annuиs leaves were lower efficient under the treatments of $H$. annuus L. plus nZVI than that by $H$. annuus alone. This is attributed to the role 
nZVI alone in degradation of thiamethoxam in soil; therefore, the concentration of thiamethoxam was more decreased in the roots and in the leaves of $H$. annuus (Table 1). Pillai and Kottekottil (2016) show that the removal of endosulfan reached $82 \%$ within 7 days when nano phytoremediation experiments were conducted with $A$. calcarata then gradually decreased, probably due to the activity of nZVI decreased over time. In addition, removal efficiency was found to be highest when nanophytoremediation experiments were conducted in soil with the TNT/nZVI ratio of $1 / 10$ with the complete TNT remediation (initial TNT concentration: $100 \mathrm{mg} / \mathrm{kg}$ ) within 60 days (Jiamjitrpanich et al., 2013). Earlier researches have proven the combination of nanoparticles and plant species performed significant contaminants removal from contaminated soil. (Ma and wang, 2010; Pillai and Jesitha, 2016 and Souri et al., 2017).

Table 1. Degradation of Thiamethoxam in soil by zero-valent iron nanoparticles plus $H$. annuus.

\begin{tabular}{|c|c|c|c|c|}
\hline \multirow[t]{2}{*}{ Treatments } & \multicolumn{4}{|c|}{ Days after treatments } \\
\hline & $\begin{array}{l}1 \text { day } \\
(\mu \mathrm{g} / \mathrm{g})\end{array}$ & $\begin{array}{l}3 \text { days } \\
(\mu \mathrm{g} / \mathrm{g})\end{array}$ & $\begin{array}{c}6 \text { days } \\
(\mu \mathrm{g} / \mathrm{g})\end{array}$ & $\begin{array}{c}12 \text { days } \\
(\mu \mathrm{g} / \mathrm{g})\end{array}$ \\
\hline \multicolumn{5}{|c|}{ SOIL } \\
\hline H. annuus & 15.32 & 14.75 & 10.73 & 4.54 \\
\hline Mar-nZVI + H. annuus & 12.35 & 9.62 & 7.02 & 2.11 \\
\hline Mor-nZVI+H. annuus & 13.02 & 9.75 & 6.17 & 3.80 \\
\hline \multicolumn{5}{|c|}{ Roots } \\
\hline H. annuus & 3.69 & 12.49 & 17.35 & 10.44 \\
\hline Mar-nZVI + H. annuus & 0.17 & 4.47 & 9.51 & 3.71 \\
\hline Mor-nZVI+ H. annuus & 1.79 & 7.92 & 11.60 & 5.72 \\
\hline \multicolumn{5}{|c|}{ Leaves } \\
\hline H. annuus & 2.23 & 5.86 & 11.83 & 16.18 \\
\hline Mar-nZVI + H. annuus & 0.16 & 2.27 & 4.18 & 10.76 \\
\hline Mor-nZVI+ H. annuus & 1.22 & 3.13 & 9.44 & 12.63 \\
\hline
\end{tabular}




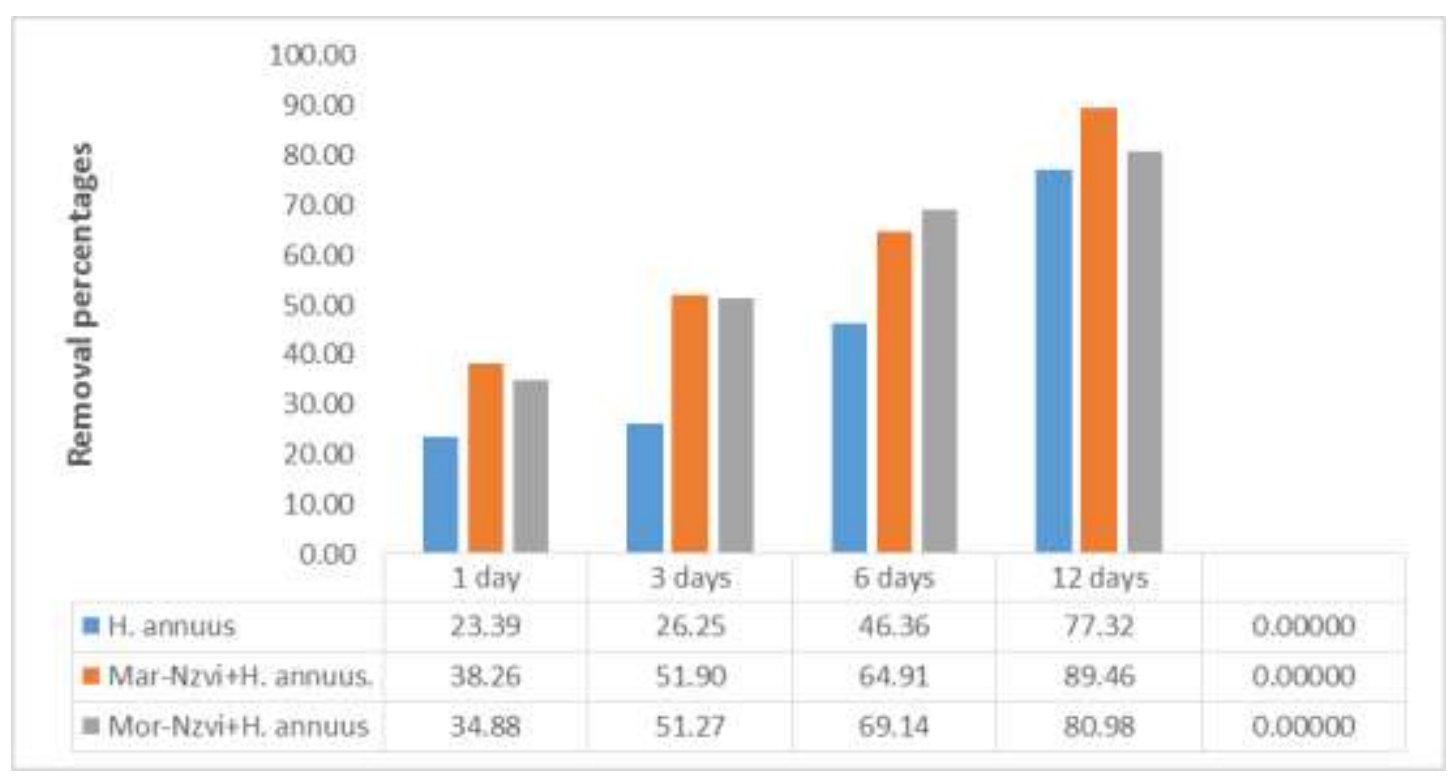

Figure (5) Percent removal of Thiamethoxam in soil by zero-valent iron nanoparticles plus $H$. annuus.

Conclusively, from these results it be concluded that helianthus annuus L. plus nZVI plays a major role for the remediation of thiamethoxamcontaminated soil.

\section{REFERENCES}

Abbassi, R., K.Y. Asheesh, K. Naresh, H. Shan and R.J. Peter(2013). Modeling and optimization of dye removal using "green"clay supported ironnano-particles. Ecological Engineering. 61, 366-370.

Asensio-Ramos, M., J. Hernández-Borges, L.M. Ravelo-Pérez and M.A. Rodríguez-Delgado (2010). Anal. Bioanal. Chem. 396, 2307.

Bar, H., D. Bhui, G.Sahoo, P. Sarkar, S. Pyne, and A.Misra (2009). Green synthesis of silver nanoparticles using seed extract of Jatropha curcas. Colloids and Surfaces A: Physicochemical and Engineering Aspects, 348(1), 212-216.

Comfort, S. D., P. J. Shea, T. A. Machacek, H. Gaber and B. T. Oh (2001). Field scale remediation of a metolachlorcontaminated spill site using zerovalent iron. Journal of Environmental Quality, 30, 1636-1643. 
De, Urzedo APFM, M.E.R. Diniz, C.C. Nascentes, R.R. Catharino, M.N. Eberlin and R.Augusti (2007). Photolytic degradation of the insecticide thiamethoxam in aqueous medium monitored by direct infusion electrospray ionization mass spectrometry. $J$ Mass Spectrom;42:1319-25.

Doong, R. a. and Y. I. Lai (2006). Effect of metal ions and humic acid on the dechlorination of tetrachloroethylene by zerovalent iron, Chemosphere, 64: 371-378.

Elliott, D.W. and W. Zhang, (2001). Field assessment of nanoscale bimetallic particles for groundwater treatment', Environmental Science and Technology, Vol. 35, No. 24, pp.4922-4926.

El-Temsah, Y. S. and E. J. Joner (2013). Effects of nano-sized zerovalent iron (nZVI) on DDT degradation in soil and its toxicity to collembola and ostracods. Chemosphere, 92(1), 131-137.

Glazier, R., R.Venkatakrishnan, F. Gheorghiu, L. Walata, R. Nash, and W. Zhang, (2003) Nanotechnology takes root', Civil Engineering, Vol. 73, No. 5, pp.64-69.

GOA (2001). Government of Australia, National Registration Authority for Agricultural and Veterinary Chemicals, Canberra, Australia.

HCPMRA(2001). Health Canada Pest Management Regulatory Agency, Regulatory Note REG2001-03. Ottawa, ON: Health Canada Pest Management Regulatory Agency.

Hoag, G.E.; J.B. Collins, J.L. Holcomb, J.R. Hoag, M.N. Nadagouda and R.S. Varma (2009).Degradation of bromothymol blue by 'greener' nano-scale zero-valent iron synthesized using tea polyphenols. J. Mater. Chem., 19, 8671-8677. [CrossRef]

Ivanov, V., J.H. Tay, S.T. Tay and H.L. Jiang (2004) Removal of microparticles by microbial granules used for aerobic wastewater treatment', Water Science and Technology, Vol. 50, No. 12, pp.147154.

Jiamjitrpanich, W., P. Parkpian, C. Polprasert and R. Kosanlavit (2013). Trinitrotoluene and Its Metabolites in Shoots and Roots of Panicum Maximum in Nano-Phytoremediation. International Journal of Environmental Science and Development (IJESD) 4: 7-10.

Joo, S. H. and F. Cheng (2006). "Nanotechnology for environmental remediation", Springer Science \& Business Media.

Khatri, N. and S.Tyagi (2015). Influences of natural and anthropogenic factors on surface and groundwater quality in rural and urban areas. Front. Life Sci. 8, 23e39. 
Khatri, N., S. Tyagi and D. Rawtani, (2016). Assessment of drinking water quality and its health effects in rural areas of Harij taluka, Patan district of northern Gujarat. Environ. Claims J. 28 (3), $223 \mathrm{e} 246$.

Kim, S. C., J. E.Yang, , Y. S. Ok, J. Skousen, D. G. Kim and J. H. Joo (2010). Accelerated metolachlor degradation in soil by zerovalent iron and compost amendments. Bulletin of Environmental Contamination and Toxicology, 84(4), 459-464.

Lehotay S.J., K.A. Son, H.Y. Kwon, U, Koesukwiwat, W. Fu, K. Mastovska, E. Hoh and N. Leepipatpiboon (2010) Comparison of QuEChERS sample preparation methods for the analysis of pesticide residuesin fruits and vegetables. J. Chromatogr, A 1217:25482560.

Ma X and C. Wang (2010). Fullerene nanoparticles affect the fate and uptake of trichloroethylene in phytoremediation systems. Environ Eng Sci 27(11):989-992.

Maddah, B. and M. Hasanzadeh (2017). Fe3O4/CNT Magnetic Nanocomposites as Adsorbents to Remove Organophosphorus Pesticides from Environmental Water., Int. J. Nanosci. Nanotechnol., 13: 139-149.

Maienfisch, P., M. Angst, F. Brandl, W. Fischer, D. Hofer, H. Kayser and et al. (2001). Chemistry and biology of thiamethoxam: a second generation neonicotinoids. Pest Manag Sci;57:906-13.

Main, A.R., J.V. Headley, K.M. Peru, N.L. Michel and Cessna C.A. AJ,Morrissey (2014).Widespread use and frequent detection of neonicotinoid insecticides in wetlands of Canada's prairie pothole region. PLOS ONE 9(3):3.

Makarov, V.V., S.S. Makarova, A.J. Love, O.V. Sinitsyna, A.O. Dudnik, I.V. Yaminsky, M.E. Taliansky and, N.O. Kalinina (2014). Biosynthesis of stable iron oxide nanoparticles in aqueous extracts of Hordeum vulgare and Rumex acetosa plants. Langmuir, 30, 59825988. [CrossRef] [PubMed].

Mauter, M. and M. Elimelech (2008) Environmental applications of carbon-based nanomaterials', Journal of Environmental Science and Technology, Vol. 42, No. 16, pp.5843-5859.

Mench, M., J. Vangronsveld, C. Beckx, and A. Ruttens (2006) Progress in assisted natural remediation of an arsenic contaminated agricultural soil', Environmental Pollution, Vol. 144, No. 1, pp.5161 . 
Mittal, A. K., Y.Chisti and U. C. Banerjee (2013). Synthesis of metallic nanoparticles using plant extracts. Biotechnology Advances, 31(2), 346-356.

Morrissey, C.A., P. Mineau, J.H. Devries, F. Sanchez-Bayo, M. Liess, M.C. Cavallaro and K .Liber (2015). Neonicotinoid contamination of global surface waters and associated risk to aquatic invertebrates: a review. Environment International, 74:291-303.

Muccio, A.D., P. Fidente, D.A. Barbini, R. Dommarco, S. Seccia and P.Morrica (2006).Application of solid-phase extraction and liquid chromatography-mass spectrometry to the determination of neonicotinoid pesticide residues in fruit and vegetables. $J$ Chromatogr ,A;1108:1-6.

Narayanan, K.B. and H.H. Park (2014). Antifungal activity of silver nanoparticles synthesized using turnip leaf extract (Brassica rapa L.) against wood rotting pathogens. European Journal of Plant Pathology, 140,185-192.

Padilla-Sanchez, J.A., P. Plaza-Bolanos, R. Romero-Gonzalez, A. Garrido-Frenich and J.L. M. Vidal (2010). Application of a quick, easy, cheap, effective, rugged and safe-based method for the simultaneous extraction of chlorophenols, alkylphenols, nitrophenols and cresols in agricultural soils, analyzed by using gas chromatography-triple quadrupole-mass spectrometry /mass spectrometry J. Chromatogr. A 1217, 5724.

Philip, D., C.Unni, S. A. Aromal, , and V.Vidhu (2011). Murraya koenigii leaf-assisted rapid green synthesis of silver and gold nanoparticles. Spectrochimica Acta Part A: Molecular and Biomolecular Spectroscopy, 78(2), 899-904.

Pillai, H. P. and K. Jesitha (2016) Nano-Phytotechnological Remediation of Endosulfan Using Zero Valent Iron Nanoparticles. Journal of Environmental Protection. 7: 734-744.

Quinn, J., C. Geiger, C. Clausen, K. Brooks, , C. Coon, S. O'Hara, T. Krug, D. Major, W.S. Yoon, A. Gavsakar and T. Holdsworth (2005). Field demonstration of DNAPL dehalogenation using emulsified zero-valent iron', Environmental Science and Technology, Vol. 39, No. 5, pp.1309-1318.

Rao, A., A. Bankar, A.R. Kumar, S. Gosavi, and S. Zinjarde (2013). Removal of hexavalent chromium ions by Yarrowia lipolytica cells modified with phyto-inspired $\mathrm{Fe} 0 / \mathrm{Fe} 3 \mathrm{O} 4$ nanoparticles. J. Contam. Hydrol., 146, 63-73. [CrossRef] [PubMed]. 
Riu, J., A. Maroto, and F. X. Rius (2006). Nanosensors in environmental analysis", Talanta, 69: 288-301.

Robinson, P. (2001).Evaluation of the new active Thiamethoxam in the product Cruiser 350 FS insecticide seed treatment. Australia: National Registration Authority for Agricultural and Veterinary Chemicals.

Satapanajaru, T., P.Anurakpongsatorn, P. Pengthamkeerati and $\mathbf{H}$. Boparai (2008). Remediation of atrazine-contaminated soil and water by nano zerovalent iron, Water, Air, Soil Pollut., 192: 349359.

Sayles, G. D., G. You, M. Wang and M. J. Kupferle (1997). DDT, DDD, and DDE dechlorination by zero-valent iron", Environ. Sci. Technol., 31: 3448-3454.

Simon-Delso, N., V. Amaral-Rogers, L. Belzunces, J Bonmatin, M. Chagnon, C. Downs, L. Furlan, D. Gibbons, C. Giorio, V. Girolami, D. Goulson, D. Kreutzweiser, C. Krupke, M. Liess, E. Long, M. Mcfield, P. Mineau, E. Mitchell, C. Morrissey, D. Noome, L. Pisa, J. Settele, J. Stark, A. Tapparo, H. Van Dyck, J. Van Praagh, J. Van der Sluijs, P. Whitehorn and M.Wiemers (2015). Systemic insecticides (neonicotinoids and fipronil): trends, uses, mode of action and metabolites. Environmental Science and Pollution Research 22(1):5-34.

Souri Z, N. Karimi, M. Sarmadi and E. Rostami (2017). Salicylic acid nanoparticle (SANPs) improves growth and phytoremediation efficiency of Isatis cappadocica Desv. under arsenic stress. IET Nanobiotechnol 11(6):650-655.

Thompson, J. M., B. J. Chisholm and A. N. Bezbaruah, (2010). Reductive dechlorination of chloroacetanilide herbicide (alachlor) using zero-valent iron nanoparticles., Environ. Eng. Sci., 27: 227232.

Wang, S., H. Sun, H.M. Ang and M.O. Tadé(2013). Adsorptive remediation of environmental pollutants using novel graphene-based nanomaterials. Chem. Eng. J. 226, 336.

Young-Soo, K. and X. Li. Qing (2003) Reduction of nitroaromatic pesticides with zero-valent iron. Chemosphere 54 (2004) 255-263.

Zheng, L.Q., G.G. Liu and D.Z. Sun. (2006).Study on the hydrolysis and photolysis of thiamethoxam. J. Harbin Inst. Technol., 38:1005-8. 


\title{
معالجة التربة الملوثة بالثياميزوكسام باستخدام تكنولوجيا النانو الخضر اءو والمعالجة النباتية
}

\author{
محمود ر اضي عبد الرحمن رمضان - عبد الحميد حسين محمد مهنا \\ أحمد علي علي رميح \\ قسم الإنتاج النباتي-كلية التكنولوجيا والتنمية-جامعة الزقازيق-مصر
}

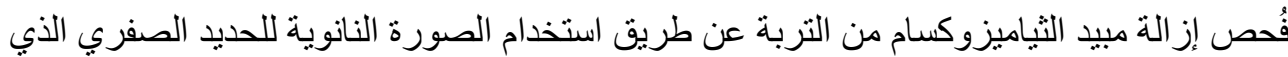

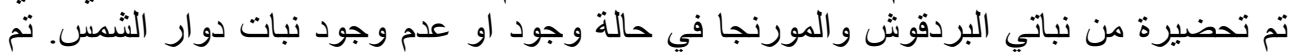

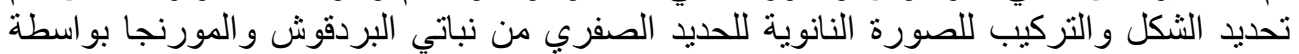

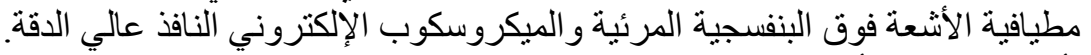

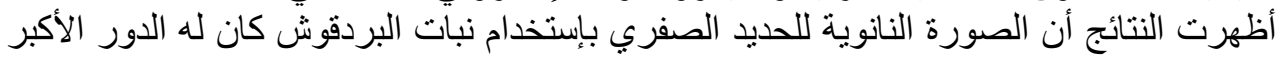

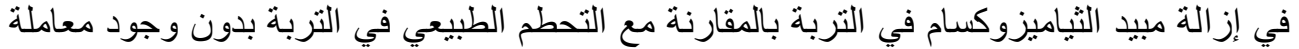

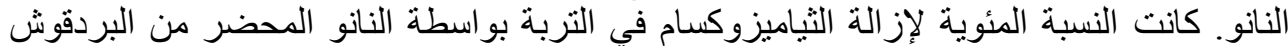

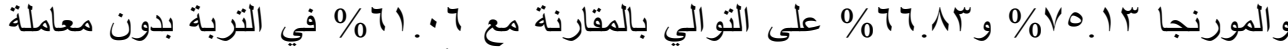

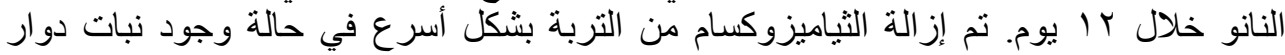

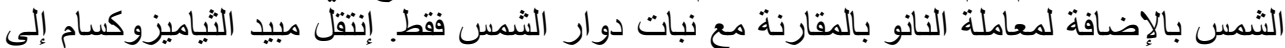

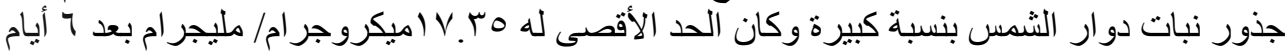

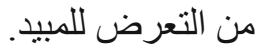

وصل مبيد الثياميزوكسام في جذور نبات دوار الثمس إلى

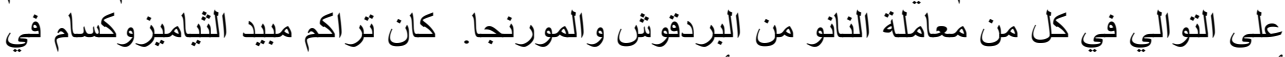

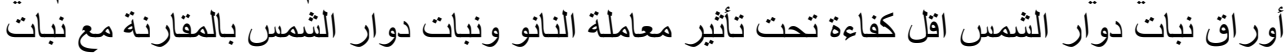

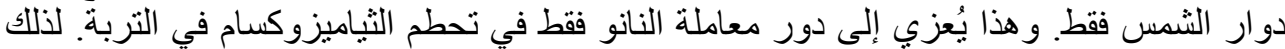

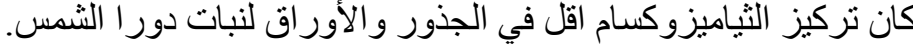

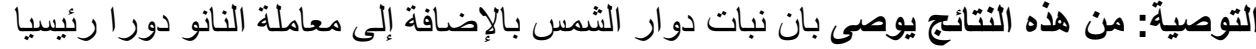
في معالجة التربة الملوثة بالثياميزوكسام. 